\title{
ANALYSIS OF SOME EMBRYOGENETIC TRAITS OF THE INTRASPECIFIC AND INTERSPECIFIC F HYBRID PLANTS G.HERBACEUM L. AND G.ARBOREUM L
}

\author{
Kh.A.Muminov \\ Institute of Genetics and Plant Experimental Biology of the Academy of Sciences of the Republic of \\ Uzbekistan Tashkent, Uzbekistan
}

Article DOI: $\underline{\text { https://doi.org/10.36713/epra4190 }}$

\begin{abstract}
In this article was given that number of anthers in intraspecific and interspecific $F_{1}$ hybrid plants obtained from crossing intraspecific varieties of the species G.herbaceum L. and G.arboreum L. were observed that was intermediate (f.harga $x$ subsp.africanum, subsp.obtusifolium $x$ subsp.nanking) and strong negative (subsp.obtusifolium $x$ subsp.perenne, f.harga $x$ subsp.perenne) than the selection material were observed and the number of pollen grains in one anther in groups obtained with the involvement of ruderal and ruderal (subsp.pseudoarboreum $x$ f.harga, f.harga $x$ subsp.pseudoarboreum, f.harga $x$ subsp.perenne, subsp.perenne $x$ f.harga) and (subsp.nanking (brown fiber) $x$ variety «VIR 1372, variety «VIR $1372 x$ subsp.nanking (brown fiber)) form with the positive heterosis. The obtained data have a kind of versatility and were defined to correspond to the data of literary sources.
\end{abstract}

KEY WORDS: species, intraspecific, interspecific, variety, form, wild, ruderal, sympodial tropical, sympodial subtropical, flower, anther, pollen, pieces.

\section{INTRODUCTION}

Cotton fiber is one of the most important unique raw materials in agriculture. Therefore, the demand for the quality of cotton fiber in our country is growing every day. Especially in recent years, our government is conducting research on the creation of precocious, high-yield, machine-harvesting, resistant to environmental stress factors, including saltresistant, drought-resistant, disease-resistant and pestresistant varieties of cotton. A set of these features is present in polymorphic species of the Gossypium L. family. So, now, the transfer of useful traits from (from) wild species to cultivated varieties using genetic selection and other modern methods remains one of the most urgent tasks of cotton growing.

One of the oldest species of the family of the genus Gossypium L. G.herbaceum L. in terms of origin and geographical distribution has a wide polymorphism. Its difference from other polymorphic species is manifested by intraspecific varieties (wild, ruderal, tropical, subtropical and cultural) with morphobiological and uniquely useful economic and valuable features.
In this regard, many scientists conducted research in various fields. In particular, several scientists emphasized that the main factors determining the genetic relationship and belonging to a separate type of cotton can be identified by determining the number of anthers and pollen grains in one anther $[1,2,4,6,8,11]$.

In scientific research by V.G.Meyer [9-10], data on the difference in the average number of anthers in one flower of the new World species G.hirsutum L., G.harknessi Brandg are given and among the old World cottons this feature is prosmoren in the species G.arboreum L., G.anomalum Wawra et Peyr, G.herbaceum L., and differences between tetraploid and diploid species in the number of anthers are also determined. It was found that in the species G.hirsutum L. the average number of anthers in one flower was 121,6 and in G.arboreum it is equal to 78,6 pieces.

Z.B.Kuryazov [2] found that cotton species belonging to different genomes $\left(\mathrm{A}_{1}, \mathrm{~A}_{2}, \mathrm{~B}_{1}, \mathrm{~B}_{2}, \mathrm{E}_{1}\right.$, $\left.\mathrm{E}_{4}, \mathrm{~F}_{1}, \mathrm{D}_{5}\right)$ and their interspecific hybrids differ significantly from each other in the number of 


\section{EPRA International Journal of Research and Development (IJRD)

anthers in a flower. As a result, he noted the uniqueness of the each studied cotton species and this feature as one of the factors of belonging to a specific taxonomic unit.

According to the results of scientific research by B.H.Amanov [1], initial materials, intraspecific and interspecific hybrids differ in the number of anthers in a flower. In the course of the study, the number of anthers in one flower in the varieties «Ash-8» and «Karshi-8» was significantly lower than in the studied species and forms. He found that the number of anthers in intraspecific and interspecific $F_{1}$ plants were intermediate or relatively high compared to the parent forms. It is also noted that in hybrid plants obtained as a result of hybridization of varieties G.darwinii Watt and G.barbadense L. the data was significantly higher on this sign.

D.V.Ter-Avanesyan [5] in his research notes that the number of anther grains in the species G.hirsutum L. can reach from 100 to 150 pieces.

\section{SOURCES AND METHODS OF EXPERIENCE}

The materials were used for the experiment as the following forms the species G.herbaceum L.: wild - subsp.africanum (Watt) Mauer, ruderal subsp.pseudoarboreum subsp.pseudoarboreum f.harga, cultural subsp.euherbaceum Mauer (variety «377»); G.arboreum L.: wild - subsp.obtusifolium (Roxb.) Mauer, subsp.obtusifolium var.indicum, ruderal subsp.perenne (Blanco) Mauer, sympodial tropical subsp.neglectum (Tod.) Mauer, subsp.neglectum f.sanguineum, sympodial subtropical - subsp.nanking (brown fiber) (Meyen) Mauer, cultural - (variety «VIR 1372») available in the gene pool of the laboratory «Experimental polyploidy and phylogeny of cotton» Institute of genetics and experimental biology of the Academy of Sciences of the Republic of Uzbekistan, data on these forms are given in the monograph published by F.M.Mauer [3].

Methods such as comparative morphology, intraspecific and interspecific hybridization, statistical and embryogenetic analysis were applied [7].

\section{RESULTS OF THE EXPERIMENTS}

It was determined that the number of anthers in one flower and the number of pollen grains in one anther in the species diversity of G.herbaceum L. and G.arboreum L. almost do not differ from each other. The number of pollen grains in the species G.herbaceum L. ranges from 55,0 to 88,8 , with the highest indicator observed in wild subspecies of this species subsp.africanum $(88,8 \pm 2,48)$. The lowest indicator was viewed in the cultural subsp.euherbaceum (variety «377»), where the number was $55,0 \pm 1,54$, which indicates equal values compared to other forms.

It was noticed that the number pollen grains in one anther are from 227.3 to 331,1 . If the highest indicator was noted in the ruderal subspecies subsp.pseudoarboreum (331,1 $\pm 9,23$ pieces), the lowest was in the wild subspecies subsp.africanum $(227,3 \pm 7,56$ pieces $)$, in the ruderal and cultural forms (229,2-270,8 pieces) (table).

The number of anthers in intraspecies in the diversity of the species G.arboreum L. is equal to 30,0-101,8 pieces, which shows the predominance than the forms of the species G.herbaceum L. by this indicator. The highest indicator for the studied by the trait was found in the wild subspecies subsp.obtusifolium var.indicum $(101,8 \pm 2,76)$, and the lowest was found in the cultural subspecies subsp.nanking (brown fiber) $(30,3 \pm 1,24)$ and other forms have relatively equal indicators $(63,5-77,3)$ for the studied feature. According to the number of pollen grains in one anther, G.arboreum L is expressed in the range of 211,3-281,1 pieces, and among the intraspecific varieties of the species were found than G.herbaceum L. If the highest indicator was observed in the tropical subspecies subsp.neglectum $(281,1 \pm 3,94$ pieces $)$, the lowest was expressed in the cultural form of the variety «VIR 1372» (211,3 $\pm 15,2$ pieces). When analyzing other forms, this indicator was 212,4-273,7 pieces and nearly equal.

For analysis intraspecific $\mathrm{F}_{1}$ hybrid plants of the species G.herbaceum L. were divided into 4 groups, where the number of anthers was 46,1-103,1 and the number of pollen grains in one anther was 190,5 - 396,4. It was noted that the highest indicator of anthers was found in a hybrid combination $F_{1}$ obtained by crossing wild and ruderal subspecies (subsp.africanum x subsp.pseudoarboreum), the value of which was $103,1 \pm 0,89$ pieces. The lowest indicator was obtained in a reciprocal combination when crossing wild and cultivated subspecies $F_{1}$ (subsp.africanum $\mathrm{x}$ 


\section{EPRA International Journal of Research and Development (IJRD) \\ Volume: 5 | Issue: 8 | August 2020 \\ - Peer Reviewed Journal}

\section{Table}

The number of anthers in one flower and pollen grains in one anther in intraspecific and interspecific $F_{1}$ hybrids and their parent forms

\begin{tabular}{|c|c|c|c|c|c|}
\hline \multirow{2}{*}{$\begin{array}{l}\text { Hybrid combinations and their parent } \\
\text { forms }\end{array}$} & \multirow{2}{*}{ 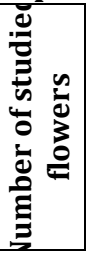 } & \multicolumn{2}{|c|}{$\begin{array}{l}\text { Number of anthers } \\
\text { pieces }\end{array}$} & \multicolumn{2}{|c|}{$\begin{array}{c}\text { Number of pollen } \\
\text { grains in one anther, } \\
\text { pieces }\end{array}$} \\
\hline & & $\bar{x} \pm \mathbf{S} \bar{x}$ & $S$ & $\bar{x} \pm \mathbf{S} \bar{x}$ & $S$ \\
\hline \multicolumn{6}{|c|}{ Parent form } \\
\hline G.herbaceum subsp. africanum & 10 & $88,8 \pm 2,48$ & 7,84 & $227,3 \pm 7,56$ & 23,8 \\
\hline G.herbaceum subsp. pseudoarboreum & 10 & $78,1 \pm 2,31$ & 7,31 & $331,1 \pm 9,23$ & 29,1 \\
\hline G.herbaceum subsp. pseudoarboreum f. harga & 10 & $65,5 \pm 2,98$ & 9,43 & $229,2 \pm 6,44$ & 20,3 \\
\hline G.herbaceum subsp. euherbaceum (variety «377») & 10 & $55,0 \pm 1,54$ & 4,85 & $270,8 \pm 10,0$ & 31,6 \\
\hline G.arboreum subsp. obtusifolium & 10 & $77,0 \pm 2,00$ & 6,32 & $235,7 \pm 5,53$ & 17,4 \\
\hline G.arboreum subsp. obtusifolium var. indicum & 10 & $101,8 \pm 2,76$ & 8,72 & $273,7 \pm 6,67$ & 21,0 \\
\hline G.arboreum subsp. neglectum & 10 & $75,9 \pm 1,48$ & 4,68 & $281,1 \pm 3,94$ & 12,4 \\
\hline G.arboreum subsp. neglectum f. sanguineum & 10 & $63,5 \pm 1,99$ & 6,28 & $233,2 \pm 9,71$ & 30,6 \\
\hline G.arboreum subsp. perenne & 10 & $77,3 \pm 2,00$ & 6,33 & $271,4 \pm 7,02$ & 22,1 \\
\hline G.arboreum subsp. nanking (brown fiber) & 10 & $30,3 \pm 1,24$ & 3,92 & $212,4 \pm 12,9$ & 40,8 \\
\hline G.arboreum (variety «VIR 1372») & 10 & $71,9 \pm 1,43$ & 4,51 & $211,3 \pm 15,2$ & 48,2 \\
\hline \multicolumn{6}{|c|}{ F1 intraspecific hybrids (G.herbaceum L.) } \\
\hline subsp. africanum x subsp. pseudoarboreum & 10 & $103,1 \pm 0,89$ & 2,81 & $204,8 \pm 1,12$ & 3,55 \\
\hline subsp. pseudoarboreum x subsp. africanum & 10 & $73,7 \pm 0,82$ & 2,58 & $190,5 \pm 0,98$ & 3,10 \\
\hline f. harga x subsp. africanum & 10 & $72,2 \pm 0,94$ & 2,97 & $225,2 \pm 1,08$ & 3,43 \\
\hline subsp. africanum x subsp. euherbaceum & 10 & $46,1 \pm 1,01$ & 3,18 & $232,3 \pm 1,78$ & 5,62 \\
\hline subsp. euherbaceum $\mathrm{x}$ subsp. africanum & 10 & $46,8 \pm 0,33$ & 1,03 & $295,5 \pm 0,43$ & 1,35 \\
\hline subsp. pseudoarboreum x f. harga & 10 & $55,7 \pm 0,94$ & 2,98 & $367,3 \pm 2,90$ & 9,15 \\
\hline f. harga x subsp. pseudoarboreum & 10 & $55,4 \pm 0,54$ & 1,70 & $372,4 \pm 0,58$ & 1,84 \\
\hline subsp. pseudoarboreum x subsp. euherbaceum & 10 & $60,4 \pm 0,91$ & 2,88 & $396,4 \pm 0,82$ & 2,59 \\
\hline subsp. euherbaceum x subsp. pseudoarboreum & 10 & $62,2 \pm 0,33$ & 1,03 & $304,5 \pm 0,54$ & 1,72 \\
\hline f. harga x subsp. euherbaceum & 10 & $47,6 \pm 0,40$ & 1,26 & $274,8 \pm 0,42$ & 1,32 \\
\hline subsp. euherbaceum x f. harga & 10 & $46,7 \pm 0,72$ & 2,26 & $294,3 \pm 0,70$ & 2,21 \\
\hline \multicolumn{6}{|c|}{ F1 intraspecific hybrids (G.arboreum L.) } \\
\hline subsp. obtusifolium x subsp. perenne & 10 & $54,7 \pm 1,19$ & 3,77 & $264,7 \pm 1,05$ & 3,34 \\
\hline subsp. perenne $\mathrm{x}$ subsp. obtusifolium & 10 & $56,0 \pm 1,05$ & 3,33 & $270,0 \pm 0,87$ & 2,75 \\
\hline var. indicum x subsp. perenne & 10 & $73,6 \pm 0,37$ & 1,17 & $194,3 \pm 0,34$ & 1,06 \\
\hline subsp. perenne $\mathrm{x}$ var. indicum & 10 & $83,6 \pm 1,01$ & 3,20 & $278,5 \pm 1,57$ & 4,97 \\
\hline subsp. neglectum $\mathrm{x}$ subsp. obtusifolium & 10 & $56,9 \pm 1,15$ & 3,65 & $229,1 \pm 0,68$ & 2,72 \\
\hline subsp. obtusifolium x f. sanguineum & 10 & $59,6 \pm 0,48$ & 0,51 & $239,4 \pm 0,50$ & 1,58 \\
\hline f. sanguineum $\mathrm{x}$ subsp. obtusifolium & 10 & $84,1 \pm 0,46$ & 1,45 & $262,9 \pm 0,64$ & 2,02 \\
\hline var. indicum x subsp. neglectum & 10 & $68,1 \pm 0,50$ & 1,60 & $328,5 \pm 0,40$ & 1,27 \\
\hline f. sanguineum $\mathrm{x}$ var. indicum & 10 & $72,8 \pm 0,74$ & 2,35 & $311,4 \pm 0,64$ & 2,01 \\
\hline var. indicum $\mathrm{x}$ f. sanguineum & 10 & $70,6 \pm 0,86$ & 2,75 & $300,2 \pm 1,07$ & 3,40 \\
\hline subsp. obtusifolium x subsp. nanking & 10 & $50,7 \pm 0,42$ & 1,34 & $249,2 \pm 0,53$ & 1,69 \\
\hline subsp. nanking x subsp. obtusifolium & 10 & $42,3 \pm 0,76$ & 2,41 & $247,3 \pm 0,78$ & 2,45 \\
\hline subsp. obtusifolium x variety «VIR 1372» & 10 & $74,6 \pm 0,96$ & 3,03 & $312,4 \pm 0,86$ & 2,72 \\
\hline variety «VIR 1372» x subsp. obtusifolium & 10 & $78,6 \pm 0,45$ & 1,43 & $236,4 \pm 0,45$ & 1,43 \\
\hline var. indicum x subsp. nanking & 10 & $68,8 \pm 0,39$ & 1,23 & $239,7 \pm 0,54$ & 1,70 \\
\hline subsp. nanking $\mathrm{x}$ var.indicum & 10 & $60,3 \pm 0,45$ & 1,42 & $319,0 \pm 0,39$ & 1,25 \\
\hline var. indicum x variety «VIR 1372» & 10 & $98,9 \pm 0,55$ & 1,73 & $281,9 \pm 0,48$ & 1,52 \\
\hline
\end{tabular}

(6) 2020 EPRA IJRD | Journal DOI: https://doi.org/10.36713/epra2016 | www.eprajournals.com |270 | 


\section{EPRA International Journal of Research and Development (IJRD)

\begin{tabular}{|c|c|c|c|c|c|}
\hline variety «VIR 1372» x var. indicum & 10 & $78,6 \pm 0,54$ & 1,71 & $356,3 \pm 0,40$ & 1,25 \\
\hline subsp. neglectum x subsp. perenne & 10 & $83,5 \pm 0,40$ & 1,27 & $322,1 \pm 0,55$ & 1,73 \\
\hline subsp. perenne $\mathrm{x}$ f. sanguineum & 10 & $76,6 \pm 0,64$ & 2,01 & $293,2 \pm 1,83$ & 5,79 \\
\hline f. sanguineum $\mathrm{x}$ subsp. perenne & 10 & $69,6 \pm 0,67$ & 2,12 & $298,7 \pm 1,01$ & 3,20 \\
\hline subsp. perenne $\mathrm{x}$ subsp. nanking & 10 & $54,4 \pm 0,40$ & 1,26 & $221,4 \pm 0,40$ & 1,26 \\
\hline subsp. nanking $\mathrm{x}$ subsp. perenne & 10 & $56,4 \pm 0,56$ & 1,78 & $299,5 \pm 0,65$ & 2,07 \\
\hline subsp. perenne x variety «VIR 1372» & 10 & $77,7 \pm 0,80$ & 2,54 & $328,3 \pm 0,40$ & 1,25 \\
\hline variety «VIR 1372» x subsp. perenne & 10 & $90,9 \pm 0,53$ & 1,66 & $235,9 \pm 0,53$ & 1,66 \\
\hline subsp. neglectum x f. sanguineum & 10 & $64,3 \pm 0,42$ & 1,34 & $358,5 \pm 0,67$ & 2,12 \\
\hline f. sanguineum $\mathrm{x}$ subsp. neglectum & 10 & $62,5 \pm 0,40$ & 1,27 & $225,2 \pm 0,55$ & 1,75 \\
\hline subsp. neglectum x subsp. nanking & 10 & $59,9 \pm 0,46$ & 1,45 & $223,3 \pm 0,37$ & 1,16 \\
\hline subsp. neglectum x variety «VIR 1372» & 10 & $81,3 \pm 1,91$ & 6,04 & $293,7 \pm 0,87$ & 2,75 \\
\hline variety «VIR 1372» x subsp. neglectum & 10 & $70,8 \pm 0,71$ & 2,25 & $277,8 \pm 0,51$ & 1,62 \\
\hline subsp. nanking $\mathrm{x}$ f. sanguineum & 10 & $47,4 \pm 0,60$ & 1,90 & $218,4 \pm 0,60$ & 1,90 \\
\hline f. sanguineum x subsp. nanking & 10 & $49,0 \pm 0,47$ & 1,49 & $208,0 \pm 0,52$ & 1,63 \\
\hline f. sanguineum x variety «VIR 1372» & 10 & $71,1 \pm 0,43$ & 1,37 & $271,5 \pm 0,40$ & 1,27 \\
\hline variety «VIR 1372» x f. sanguineum & 10 & $55,8 \pm 0,39$ & 1,23 & $212,8 \pm 0,39$ & 1,23 \\
\hline subsp. nanking x variety «VIR 1372» & 10 & $68,0 \pm 0,83$ & 2,62 & $233,8 \pm 0,61$ & 1,93 \\
\hline variety «VIR 1372» x subsp. nanking & 10 & $48,5 \pm 0,40$ & 1,27 & $312,5 \pm 0,43$ & 1,35 \\
\hline
\end{tabular}

F1 interspecific hybrids (G.herbaceum L. x G.arboreum L./ G.arboreum L. x G.herbaceum L.)

\begin{tabular}{|c|c|c|c|c|c|}
\hline subsp. africanum $\mathrm{x}$ subsp. obtusifolium & 10 & $57,2 \pm 1,56$ & 4,92 & $261,6 \pm 0,75$ & 2,37 \\
\hline subsp. africanum $\mathrm{x}$ var. indicum & 10 & $71,5 \pm 1,10$ & 3,50 & $229,6 \pm 1,86$ & 5,91 \\
\hline subsp. africanum $\mathrm{x}$ subsp. perenne & 10 & $75,4 \pm 0,64$ & 2,01 & $237,9 \pm 0,59$ & 1,85 \\
\hline subsp. perenne $\mathrm{x}$ subsp. africanum & 10 & $65,8 \pm 1,23$ & 3,88 & $276,8 \pm 0,77$ & 2,44 \\
\hline subsp. pseudoarboreum x subsp. obtusifolium & 10 & $70,9 \pm 1,34$ & 4,23 & $314,9 \pm 0,80$ & 2,51 \\
\hline subsp. obtusifolium x subsp. pseudoarboreum & 10 & $74,4 \pm 0,91$ & 2,88 & $260,0 \pm 1,05$ & 3,33 \\
\hline var. indicum x subsp. pseudoarboreum & 10 & $88,2 \pm 0,51$ & 1,62 & $247,4 \pm 0,62$ & 1,96 \\
\hline subsp. pseudoarboreum x var. indicum & 10 & $85,6 \pm 1,16$ & 3,68 & $243,6 \pm 1,54$ & 4,88 \\
\hline f. harga x subsp. obtusifolium & 10 & $71,3 \pm 2,30$ & 7,30 & $231,3 \pm 1,83$ & 5,81 \\
\hline subsp. neglectum $\mathrm{x}$ subsp. africanum & 10 & $90,3 \pm 1,00$ & 3,16 & $277,2 \pm 0,76$ & 2,39 \\
\hline subsp. africanum $\mathrm{x}$ f. sanguineum & 10 & $70,0 \pm 1,02$ & 3,23 & $230,4 \pm 1,12$ & 3,53 \\
\hline f. sanguineum $\mathrm{x}$ subsp. africanum & 10 & $82,2 \pm 0,84$ & 2,66 & $235,0 \pm 1,03$ & 3,27 \\
\hline subsp. africanum x subsp. nanking & 10 & $56,7 \pm 0,45$ & 1,42 & $274,7 \pm 0,50$ & 1,57 \\
\hline subsp. nanking x subsp. africanum & 10 & $62,1 \pm 0,53$ & 1,66 & $254,2 \pm 0,61$ & 1,93 \\
\hline subsp. pseudoarboreum x subsp. perenne & 10 & $87,0 \pm 1,51$ & 4,78 & $284,7 \pm 2,63$ & 8,31 \\
\hline subsp. perenne $\mathrm{x}$ subsp. pseudoarboreum & 10 & $79,9 \pm 1,10$ & 3,48 & $254,1 \pm 1,96$ & 6,19 \\
\hline f. harga $\mathrm{x}$ subsp. perenne & 10 & $48,0 \pm 0,47$ & 1,49 & $324,0 \pm 0,49$ & 1,56 \\
\hline subsp. perenne x f. harga & 10 & $44,7 \pm 1,26$ & 3,99 & $322,0 \pm 1,57$ & 4,98 \\
\hline subsp. neglectum x subsp. pseudoarboreum & 10 & $88,2 \pm 1,26$ & 3,97 & $324,8 \pm 1,54$ & 4,87 \\
\hline subsp. pseudoarboreum x f. sanguineum & 10 & $87,0 \pm 0,47$ & 1,49 & $344,0 \pm 0,56$ & 1,76 \\
\hline f. sanguineum $\mathrm{x}$ subsp. pseudoarboreum & 10 & $85,0 \pm 0,47$ & 1,49 & $339,0 \pm 0,52$ & 1,63 \\
\hline f. harga $\mathrm{x}$ subsp. neglectum & 10 & $63,0 \pm 0,47$ & 1,49 & $335,0 \pm 0,49$ & 1,56 \\
\hline subsp. neglectum $\mathrm{x}$ f. harga & 10 & $74,0 \pm 0,47$ & 1,49 & $277,1 \pm 0,50$ & 1,60 \\
\hline f. harga $\mathrm{x}$ f. sanguineum & 10 & $70,0 \pm 0,47$ & 1,49 & $243,0 \pm 0,49$ & 1,56 \\
\hline f. sanguineum $\mathrm{x}$ f. harga & 10 & $52,4 \pm 0,45$ & 1,43 & $325,4 \pm 0,45$ & 1,43 \\
\hline subsp. pseudoarboreum x subsp. nanking & 10 & $56,8 \pm 1,32$ & 4,18 & $331,0 \pm 2,87$ & 9,07 \\
\hline subsp. nanking $\mathrm{x}$ subsp. pseudoarboreum & 10 & $57,4 \pm 0,92$ & 2,91 & $313,3 \pm 1,42$ & 4,50 \\
\hline f. harga x subsp. nanking & 10 & $68,0 \pm 0,47$ & 1,49 & $267,8 \pm 0,39$ & 1,23 \\
\hline subsp. nanking $\mathrm{x}$ f. harga & 10 & $54,5 \pm 0,50$ & 1,58 & $238,4 \pm 0,48$ & 1,51 \\
\hline
\end{tabular}




\section{EPRA International Journal of Research and Development (IJRD)

subsp.euherbaceum (variety «377»)) (46,1-46,8 pieces), in which the amplitude of variability averaged $42-50$ and $45-48$ pieces, and the coefficient of variation was $2.2 \%$ and $6.8 \%$, respectively.

In reciprocal hybrid combinations involving other groups, the indicators were relatively equal in the number of anthers per flower (47,4-90,9 pieces). The amplitude of variation average 45-50 pieces and 88-93 pieces respectively and the coefficient of variation was $4.0 \%$ and $1.8 \%$ respectively. The highest indicator of pollen grains in a anther $(358,5$ pieces) was observed in a hybrid combination $F_{1}$ (subsp.neglectum x subsp.neglectum f.sanguineum) with the participation of tropical subspecies and forms, where the amplitude of variability averaged 365-361 pieces, and the coefficient of variation $0.59 \%$.

This showed that $F_{1}$ hybrids of the species G.herbaceum L. were predominate by the number of pollen grains in one anther. In the hybrid combination $\mathrm{F}_{1}$ (subsp.obtusifolium var.indicum $\mathrm{x}$ subsp.perenne) with the participation of wild and ruderal subspecies and forms, the lowest indicator of pollen grains in one anther was observed (194,3 \pm $0,34)$ with the average amplitude of 193-196 pieces, and the coefficient of variation was $0.55 \%$.

In reciprocal hybrid combinations of $F_{1}$ hybrids with other studied forms, the number of pollen grains in one anther was almost equal (208,0356,3 pieces), the amplitude of variability average 206-210 and 355-358 pieces respectively with the coefficient of variation equal to $0,79 \%$ and $0,35 \%$ respectively.

When we analyzed interspecific $\mathrm{F}_{1}$ hybrids of the species G.herbaceum L. and G.arboreum L. divided into 7 groups, number of anthers was 44,790,3 pieces, and the number of pollen grains in one anther - 229,6-344,0 pieces and intraspecific $F_{1}$ hybrids of the species G.herbaceum L., G.arboreum L. showed relatively low indicator on the studied characteristics. If the largest number of anthers is observed in $\mathrm{F}_{1}$ hybrids obtained with the participation of subspecies and forms of the species G.herbaceum L. and G.arboreum L. in a combination of wild and tropical forms of $\mathrm{F}_{1}$ (subsp.neglectum $\mathrm{x}$ subsp.africanum), where the number of pollen grains is $90,3 \pm 1,00$ pieces, the smallest number of anthers was determined in the hybrid combination of the ruderal form $\mathrm{F}_{1}$ (subsp.pseudoarboreum f.harga $\mathrm{x}$ subsp.perenne) and was 44,7-48,0 pieces. At the same time, the amplitude of variability was on average 40-52 and 46-50 pieces, and the coefficient of variation $-8.9 \%$ and $3.1 \%$ respectively. Reciprocal hybrid combinations involving other forms were relatively equal (52,4-88,2 pieces), with an average variation amplitude of 50-54 and 83-94 pieces, with the coefficient variation of $2,7 \%$ and $4,5 \%$ respectively.
The largest number of pollen grains in the anther (339-344 pieces) was observed in a combination of reciprocal $F_{1}$ hybrid plants attracted by crossing ruderal and tropical subspecies (subsp.pseudoarboreum $\mathrm{x}$ subsp.neglectum f.sanguineum). The amplitude of variation average 337-341 and 342-346 and the coefficient of variation was $0,51 \%$ and $1,5 \%$, respectively. According to the studied trait, the lowest indicator was observed in $\mathrm{F}_{1}$ plants in a hybrid combination (subsp.africanum $\mathrm{x}$ subsp.obtusifolium var.indicum) $(229,6 \pm 1,86$ pieces), where the average amplitude of variability is 220-237 pieces, and the coefficient of variation is 2,5 $\%$. In reciprocal hybrid combinations obtained by crossing other groups, the number of pollen grains in one anther is relatively equal $(231,3-339,0)$ with an average amplitude of 225-240 and 337-341 respectively and the coefficient of variation $2,5 \%$ and $0,48 \%$, respectively.

The indicators of the studied traits was showed that the difference both in the parent forms and in intraspecific and interspecific hybrids. The number of anthers in the studied cultural subspecies subsp.euherbaceum (variety «377») and subsp.nanking (brown fiber) was significantly less than in other studied subspecies and forms, including wild subsp.africanum $227,3 \pm 7,56$, as well as in the subspecies subsp.nanking (brown fiber) belonging to the species and G.arboreum L. and in the form (variety «VIR 1372»), where this indicator was 212,4-211,3 pieces.

\section{CONCLUSIONS}

The number of anthers in intraspecific and interspecific $\mathrm{F}_{1}$ hybrid plants obtained from crossing intraspecific varieties of the species G.herbaceum L. and G.arboreum L. were observed that was intermediate (f.harga x subsp.africanum, subsp.obtusifolium $\mathrm{x}$ subsp.nanking) and strong negative (subsp.obtusifolium $\mathrm{x}$ subsp.perenne, f.harga $\mathrm{x}$ subsp.perenne) than the selection material were observed and the number of pollen grains in one anther in groups obtained with the involvement of ruderal and ruderal (subsp.pseudoarboreum $\mathrm{x}$ f.harga, f.harga x subsp.pseudoarboreum, f.harga x subsp.perenne, subsp.perenne $\mathrm{x}$ f.harga) and (subsp.nanking (brown fiber) x variety «VIR 1372, variety «VIR 1372 x subsp.nanking (brown fiber)) form with the positive heterosis. The obtained data have a kind of versatility and correspond to the data of literary sources.

\section{REFERENCE}

1. Amanov B.H. Inheritance of genetic diversity and morpho-economic characteristics of Peruvian cotton.: Doctor of Philosophy (PhD) of Biological Sciences.- 2010. - P. 34-42. 


\section{EPRA International Journal of Research and Development (IJRD)}

Volume: 5 | Issue: 8 | August 2020

- Peer Reviewed Journal

2. Kuryazov Z.B. Intergenetic relatedness of African-Asian cotton species and phylogenetic relationship with American cotton G.raimondi Ulbr.: author... Doctor of Philosophy $(P h D)$ of Biological Sciences.- 2002. - P. 12-13.

3. Mauer F.M. Origin and systematics of cotton. // in the book: cotton.- Tashkent: Fan, 1954. - Vol. 1. $-384 p$.

4. Rizaeva S.M. Distant hybridization of cotton and obtaining new donors (using the example of the New World species): Diss. ... doc biol. Science.Tashkent: R\&D "Biolog”, Academy of Sciences of the Republic of Uzbekistan, 1996.- 289 p.

5. Ter-Avanesyan D.V. Cotton Blend // Leningrad: Kolos, 1973. - 483 p.

6. Ernazarova Z.A. Interspecific relationship of $C$ genomic cottons and their phylogenetic relationships with D-genomic species: author. Doctor of Philosophy (PhD) of Biological Sciences.- 1998. - B. 16-17.

7. Abdurakhmonov I.Y., Abdullaev A., Buriev Z., Shermatov Sh., Kushanov F.N., Makamov A., Shapulatov U., Egamberdiev Sh.S., Salakhutdinov I.B., Auybov M., Darmanov M., Rizaeva S.M., Abdullaev F., Nomozov Sh., Khalikova M., Saydaliev H., Avtonomov V.A., Snamyan M., Duiesenov T.K., Musaev J., Abdullaev A.A., Abdukarimov A. Cotton germplasm collection of Uzbekistan.//In book: World Cotton Germplasm Collection.- Chapter 11.- Ed. Abdurakhmanov I.Y.- Intech, 2014.- P. 289-309.

8. Bajaj Y.PS., Gill M.S. (1989) Pollenembryogenesis and chromosomal variation in anther culture of a diploid cotton (Gossypium arboreum L.). SABRAO J 21:57-63

9. Meyer V.G. Cytoplasmic effects on anther numbers in interspecific hybrids of cotton. II. G.herbaceum and G.harknessi.//J.: Heredity, 1971.- Vol. 62. - № 2.- P. 77-78.

10. Meyer V.G. Cytoplasmic effects on anther numbers in interspecific hybrids of cotton. III. G.longicalyx.//J.: Heredity.- 1972.- Vol. 63.- № 1.- P. 33-34.

11. Omran A., Asadollah A., Saiid N. Intragenomic diversity and geographical adaptability of diploid cotton species revealed by cytogenetic studies.//African Journal of Biotechnology.2007.- Vol. 6.- № 12.- P. 1387-1392. 